\title{
ROOTSTOCKS EFFECTS ON THE PHYSICOCHEMICAL CHARACTERISTICS OF BORDÔ, ISABEL AND IAC 138-22 MÁXIMO MUST AND WINE ${ }^{1}$
}

\author{
MARLON JOCIMAR RODRIGUES DA SILVA², LUCIANA TREVISAN BRUNELLI ${ }^{3}$, \\ MARA FERNANDES MOURA ${ }^{4}$, JOSÉ LUIZ HERNANDES 5 , \\ SARITA LEONEL ${ }^{6}$, MARCO ANTONIO TECCHIO $^{6}$
}

\begin{abstract}
It has been demonstrated that rootstocks can influence grape characteristics, but there are few data in literature about the rootstocks influence in the wine characteristics, especially in wines elaborated with Vitis labrusca or hybrid grapes. This study evaluated the influence of 'IAC 766' and '106-8 Mgt' rootstocks on the physicochemical characteristics of 'Bordô', 'Isabel' and 'IAC 138-22 'Máximo' musts and wines. The musts were evaluated for $\mathrm{pH}$, soluble solids, total acidity and soluble solids/acidity ratio. The wines were evaluated for density, alcohol content; total, volatile and fixed acidity; $\mathrm{pH}$, dry extract, reducing sugars, reduced dry extract, alcohol in weight/reduced dry extract; free and total sulfur dioxide; anthocyanins, polyphenols index (I 280); polyphenols and total flavonoids and antioxidant activity. The 'Bordô', 'Isabel' and IAC 13822 'Máximo' musts had low soluble solids for winemaking. The '106-8 Mgt' rootstock promoted higher dry extract content and reduced dry extract in Bordô wine, and lower total and fixed acidity in IAC 138-22 Máximo wine. In Isabel wine, higher $\mathrm{pH}$ was promoted by the 'IAC 766' rootstock. Aside from low total acidity of the Bordô wine, all the physicochemical characteristics of the wines studied are in accordance with Brazilian law. There was no effect of rootstocks in the phenolics content and antioxidant activity of wines. Index terms: Vitis sp., table wine, classical analysis, phenolic compounds, antioxidant activity.
\end{abstract}

\section{INFLUÊNCIA DE PORTA-ENXERTOS NAS CARACTERÍSTICAS FÍSICO-QUÍMICAS DO MOSTO E DOS VINHOS BORDÔ, ISABEL E IAC 138-22 MÁXIMO}

RESUMO - Tem sido demostrado que os porta-enxertos podem influenciar as características da uva, no entanto, há poucos dados na literatura sobre o efeito dos porta-enxertos nas características dos vinhos, especialmente quando elaborados com uvas Vitis labrusca ou híbridas. O objetivo do trabalho foi avaliar a influência de porta-enxertos nas características físico-químicas dos mostos e vinhos Bordô, Isabel e IAC 138-22 Máximo. Foram utilizadas uvas 'Bordô', 'Isabel' e IAC 138-22 'Máximo', enxertadas sobre os porta-enxertos 'IAC 766' e '106-8 Mgt'. Os mostos foram avaliados pelo $\mathrm{pH}$, sólidos solúveis, acidez total e relação sólidos solúveis/acidez. Nos vinhos, avaliou-se: densidade, teor alcoólico, acidez total, volátil e fixa; $\mathrm{pH}$, extrato seco, açúcares redutores, extrato seco reduzido, álcool em peso/extrato seco reduzido; dióxido de enxofre livre e total; antocianinas, índice de polifenóis (I 280); polifenóis e flavonoides totais e atividade antioxidante. Os mostos das uvas 'Bordô', 'Isabel' e IAC 138-22 'Máximo' apresentaram baixos teores de sólidos solúveis para vinificação. O porta-enxerto '106-8 Mgt' promoveu maior teor de extrato seco e extrato seco reduzido no vinho Bordô, e menor acidez total e fixa no vinho IAC 138-22 Máximo. No vinho Isabel, maior $\mathrm{pH}$ foi promovido pelo porta-enxerto 'IAC 766'. Com exceção da baixa acidez total do vinho Bordô, todas as características físico-químicas dos vinhos estudados estão de acordo com a legislação brasileira. Não houve efeito dos porta-enxertos nos teores de compostos fenólicos e na atividade antioxidante dos vinhos. Termos para indexação: Vitis sp., vinhos de mesa, análises clássicas, compostos fenólicos, atividade antioxidante.

\footnotetext{
1(Paper 050-16) Part of the first author's masters dissertation. Research project funded by Fundação de Amparo à Pesquisa do Estado de São Paulo (FAPESP).

${ }^{2}$ Agronomist engineer, PhD student in Agronomy (Horticulture), São Paulo State University (UNESP), School of Agriculture, Botucatu, São Paulo, Brazil. E-mail: marlonjocimar@gmail.com

${ }^{3}$ Agronomist engineer, PhD in Agronomy, UNESP, School of Agriculture. E-mail: lutbrunelli@gmail.com

${ }^{4}$ Agronomist engineer, PhD in Agronomy, scientific researcher at the Centro APTA de Frutas, Instituto Agronômico, Jundiaí, São Paulo, Brazil. E-mail: mouram@iac.sp.gov.br

${ }^{5}$ Biologist, scientific researcher at the Centro APTA de Frutas, Instituto Agronômico. E-mail: jlhernandes@iac.sp.gov.br

${ }^{6}$ Agronomist engineer, PhD in Agronomy, Professor of São Paulo State University, School of Agriculture. E-mail: sarinel@fca.unesp.br; tecchio@fca.unesp.br
} 


\section{INTRODUCTION}

The grapes from species Vitis vinifera $\mathrm{L}$. are the most used for the preparation of wine worldwide, especially in the traditional wine-producing countries of Europe. In contrast, in Brazil, more than $85 \%$ of the volume of processed grapes come from American grapes, especially Vitis labrusca L., or a hybrid, since these plants are adapted for the climatic conditions in the Brazil, especially at harvest time in the South and Southeast (LAGO-VANZELA et al., 2011; BIASOTO et al., 2014).

Both in Rio Grande do Sul, Brazil largest wine producer, and in the state of São Paulo, especially in the eastern region of the state around the city of Jundiaí, V. labrusca varieties, such as 'Isabel' and 'Bordô', represent an important portion of the cultivation area of grapes and production of wines (RIZZON; MIELE, 2006; TECCHIO et al., 2007). With the increase in rural tourism and the growing interest in artisanal wine, the hybrid wine grape IAC 138-22 'Máximo' has become an important grape in recent years in wine-producing areas in the east of the state of São Paulo (HERNANDES et al., 2010).

V. labrusca and hybrid grapes have a "foxy" flavor, due to anthranilate methyl ester, which gives their wines a fruity flavor. Although this feature is condemned by many, especially by the traditional wine-producing european countries specialized in fine wines, the fruity taste of table wines is widely demanded by large number of wine consumers in Brazil (RIZZON et al., 2000; HERNANDES et al., 2010; BIASOTO et al., 2014).

Many factors influence the physical and chemical composition of the wine, such as the grape cultivar, the degree of ripeness of the grapes at harvest, climate conditions, and cultural practices adopted in the production of wine (BURIN et al., 2011); all of these factors can be influenced by rootstock and will determine the quality of the final product. Several studies show that the rootstock influences the physicochemical characteristics of the grape (ORLANDO et al., 2008; MOTA et al., 2009; SATO et al., 2009), however, there are few data in the literature that show that the rootstock influences the physicochemical characteristics of the wines. Then, the objective of the study was to evaluate the influence of rootstocks on the physicochemical characteristics of 'Bordô', 'Isabel' and IAC 138-22 'Máximo' musts and wines.

\section{MATERIAL AND METHODS}

The experiment was conducted in Botucatu, SP, from December 2013 to October 2014 with 'Bordô', 'Isabel' and IAC 138-22 'Máximo' grapevines, grafted on 'IAC 766' and '106-8 Mgt' rootstocks. The vines were grown in Jundiaí, $\operatorname{SP}\left(23^{\circ}\right.$ $06^{\prime} \mathrm{S}, 46^{\circ} 55^{\prime} \mathrm{W}$ and $745 \mathrm{~m}$ above sea level).

According to the Köppen classification, the climate is $C f b$, with average annual rainfall of 1400 $\mathrm{mm}$, an average temperature of $19.5^{\circ} \mathrm{C}$ and relative humidity of $70.6 \%$. The mean values of average temperature and rainwater content at the harvest time was $23.7^{\circ} \mathrm{C}$ and $65 \mathrm{~mm}$ in December, and $25.2{ }^{\circ} \mathrm{C}$ and $142.6 \mathrm{~mm}$ in January, respectively.

The vines were 4 years old and were conducted in an experimental vineyard, trained in high trellis system with 2.5 and 1.0 meters of spacing between lines and plants, respectively. The bunches were harvested according to soluble solids, titratable acidity and $\mathrm{pH}$ content of each ripened cultivar (HERNANDES et al., 2010) and transported to laboratory, where they were microvinified according to the classical method of vinification (ROSIER, 1995).

The grapes were manually stripped, weighed (10 kg grapes per experimental plot), crushed in manual crushing rollers and placed in PVC barrels with 20 L capacity, which must samples were collected to measure chemical composition. A $10 \%$ potassium metabisulfite solution $(80 \mathrm{mg}$ $\mathrm{kg}^{-1}$ of grapes) was added with active dry yeast (Saccharomyces cerevisiae) in the proportion of 0.2 $\mathrm{g} \mathrm{kg}^{-1}$ of grapes. The barrels remained in temperaturecontrolled room $\left(20 \pm 2{ }^{\circ} \mathrm{C}\right)$ for 7 days (soaking time), when the must was filtered and strained with a perforated basket.

Because the amount of sugar in the must was insufficient to achieve suitable alcohol content, the correction was performed with crystal sugar to raise the concentration of must up to $20^{\circ} \mathrm{Brix}$, and the correction performed in two stages: $50 \%$ sugar added on the 2nd day of fermentation and $50 \%$ at running off. The musts were transferred to glass bottles with a capacity of $4.5 \mathrm{~L}$ equipped with Müller valve and kept standing at room temperature to complete the malolactic fermentation. After separating the precipitated the wine was bottled, using $750 \mathrm{~mL}$ bottles sealed with corks. The bottles remained at room temperature for four months before analysis.

The musts were analyzed by determinations of soluble solids ( $\mathrm{SS},{ }^{\circ} \mathrm{Brix}$ ), by direct refractometry; total acidity (TA, meq $\mathrm{L}^{-1}$ ) determined by titration with $0.1 \mathrm{~N}$ of $\mathrm{NaOH}$ until equivalent point at $\mathrm{pH}$ 
8.2; SS/TA ratio, and $\mathrm{pH}$, using the Tecnal ${ }^{\circledR} \mathrm{pH}$ meter (BRASIL, 2005).

The wines were analyzed for density ( $\mathrm{g}$ $\mathrm{mL}^{-1}$ ), in densimeter Mettler ${ }^{\circledR}$ model KEM DA310; alcohol content $(\%, \mathrm{v} / \mathrm{v})$ by distillation of the alcohol in wines; total acidity $\left(\mathrm{meq} \mathrm{L}^{-1}\right)$ by titration with $0.1 \mathrm{~N}$ of $\mathrm{NaOH}$ in the presence of $1 \%$ phenolphthalein; volatile acidity $\left(\right.$ meq $\left.\mathrm{L}^{-1}\right)$ after distillation and subsequent titration with $0.1 \mathrm{~N}$ of $\mathrm{NaOH}$, in the presence of phenolphthalein; fixed acidity (meq $\mathrm{L}^{-1}$ ) obtained by difference between the total acidity and volatile acidity; and $\mathrm{pH}$ in $\mathrm{pH}$ meter, calibrated with $\mathrm{pH}$ buffer solutions $\mathrm{pH} 3.0$ and 7.0 (BRASIL, 2005). Dry extract $\left(\mathrm{g} \mathrm{L}^{-1}\right)$ was determined by evaporation in a water bath of $25 \mathrm{~mL}$ of wine and then heating the residue in an oven $\left(100 \pm 5^{\circ} \mathrm{C}\right)$ to constant weight; the reduced dry extract $\left(\mathrm{g} \mathrm{L}^{-1}\right)$ and the alcohol in weight/reduced dry extract $\left(\mathrm{g} \mathrm{L}^{-1}\right)$ according to Rizzon (2010). Reducing sugars $\left(\mathrm{g} \mathrm{L}^{-1}\right)$ were determined by colorimetric method of SomogyNelson, based on the analytical curve of glucose and readings made at $510 \mathrm{~nm}$ (NELSON, 1944) and free and total sulfur dioxides $\left(\mathrm{mg} \mathrm{L}^{-1}\right)$ obtained according to the methodology of Rizzon et al. (2003).

For the determination of polyphenol index (I 280), wines were diluted at a ratio of $1 \%$ and the absorbance determined spectrophotometrically at $280 \mathrm{~nm}$, using quartz cuvettes with $1 \mathrm{~cm}$ optical path (RIZZON, 2010). The total polyphenol content (mg L-1 of gallic acid equivalent) was determined using the Folin-Ciocalteu reagent (SINGLETON; ROSSI, 1965). The reading was performed at $725 \mathrm{~nm}$ in a spectrophotometer UV/vis and content of total polyphenols calculated using standard curve of gallic acid. The total flavonoids were determined according to the method described by Popova et al. (2004), with adaptations. The absorbance was measured at 425 $\mathrm{nm}$ and the contents calculated by standard curve of quercetin and the results are expressed in $\mathrm{mg} \mathrm{L}^{-1}$ equivalent of quercetin $\left(\mathrm{mg} \mathrm{L}^{-1}\right)$.

Anthocyanins were determined according Rizzon (2010). In a test tube was placed $1 \mathrm{ml}$ of each sample of red wine, $1 \mathrm{ml}$ of ethanol with 0.1 $\%$ hydrochloric acid and $10 \mathrm{ml}$ of $2 \%$ hydrochloric acid solution. In a second vial was added $1 \mathrm{~mL}$ of wine, $1 \mathrm{~mL}$ of ethanol with $1 \%$ hydrochloric acid and $10 \mathrm{~mL}$ of $\mathrm{pH} 3.5$ buffer solution. It was executed, then, the absorption reading of two samples tubes in a spectrophotometer at $520 \mathrm{~nm}$. The concentration of free anthocyanins, in $\mathrm{m} \mathrm{L} \mathrm{L}^{-1}$ was obtained relating the optical density differences to an established standard curve, and anthocyanins $\left(\mathrm{mg} \mathrm{L}^{-1}\right)=388 \times \Delta \mathrm{d}$, where: $\Delta \mathrm{d}=$ reading difference between the two tubes.

The antioxidant activity was determined according to the methodology of Brand-Williams et al. (1995), as changed by Rossetto et al. (2009). The DPPH solution was initially prepared in ethanol. A negative control was prepared with DPPH (300 $\mathrm{uL}$ ) in ethanol. Readings were taken at $517 \mathrm{~nm}$ and converted into a percentage of antioxidant capacity by the following equation: \% reduction of DPPH $=[($ control Abs - Abs sample $) /$ control Abs $] / 100$. A calibration curve was prepared with standard Trolox, and the results were expressed in mg Trolox equivalent $\mathrm{g}^{-1}$ sample.

The vines were grown in randomized block design in split plots, with five blocks and six plants per subplot, with the plots represented by the rootstocks and the subplots by the cultivars. The microvinifications were made with grapes from three blocks. The choice of the three blocks was made based on the grapes maturation uniformity and its yield. Blocks with yield above the minimum required for each microvinification were selected. Thus there were three microvinifications per treatment, totaling 18 microvinifications. However, the musts and wines from Bordô, Isabel and IAC 138-22 Maximum grapevines were analyzed separately, considering the rootstocks as treatments in each wine. Thus, for analysis of must and wine, it was used a completely randomized design with two treatments (rootstocks) and three repetitions (microvinifications). All analyzes were performed in triplicate and the mean in each plants were submitted to ANOVA and compared by Tukey test at $5 \%$ probability through the SISVAR statistical program.

\section{RESULTS AND DISCUSSION}

There was no effect of the 'IAC 766' and '106-8 Mgt' rootstocks in the 'Isabel' and IAC 138-22 'Máximo' pH musts (Table 1). In the 'Bordô' must, the $\mathrm{pH}$ of the grapes grafted on '106-8 Mgt' rootstock was higher than that obtained when grafted on 'IAC 766 ' rootstock, with average values 3.69 and 3.65, respectively. These values are considered suitable for wine grapes.

The soluble solids content did not differ between the rootstocks in the 'Bordô', 'Isabel' and IAC 138-22 'Máximo' musts with averages values $17.4 ; 18.1$ and $15.5^{\circ} \mathrm{Brix}$, respectively. These results are in agreement with Hernandes et al. (2010). According to these authors, the soluble solids obtained in grapes from wine grown in the Jundiaí region are generally low. This is mainly due to the ripening and harvest periods the grapes occurs at a time of the year when there is heavy rainfall and high temperatures both in days and nights, plus 
there possible genetic limitations of grape cultivars. The soluble solids content of grapes for wine is an important characteristic for the final quality of the product, since it determines the need or not of chaptalization to reach the minimum alcoholic strength required for the wine, which should be at least $10.5 \%$ (v/v) (RIZZON et al., 1994).

In Bordô and Isabel cultivars, there was no influence of rootstocks in the total acidity of the grapes' musts, and the averages of 45.87 and $106.5 \mathrm{meq} \mathrm{L}^{-1}$, respectively, whereas in IAC 138-22 Máximo cultivar the 'IAC 766' rootstock had higher value in the total wine acidity, compared to '106-8 Mgt' rootstock.

For Isabel and IAC 138-22 Máximo musts, there was no difference between the rootstocks in soluble solids/total acidity (SS/TA) ratio, and the mean values were 22.73 and 19.25 , respectively. In the Bordô must, it obtained higher value of SS/TA ratio in grapes grafted on '106-8 Mgt' rootstock. This relationship is one of the grape maturation indices and their enological quality; however, its use should be done carefully, as an increase in sugar does not always correspond to the same reduction in total acidity. It is also not indicated for comparing musts of different grape plants (RIZZON et al., 2000).

Rootstocks differ widely in vigor as a result of different nutritional requirements and capacity for water and nutrient absorption because its roots have selectivity in absorption of ions in the soil solution that can directly influence the yield and quality characteristics of the vine (TECCHIO et al., 2014). Although the 'IAC 766' rootstock is considered more vigorous than the '106-8 Mgt' rootstock, there was no significant difference in determined characteristics of both must and wine in this study, corroborating with the results obtained by Silva et al. (2015), who also found few effect of the 'IAC 766' and '106-8 Mgt' rootstocks in the must and white wine of the IAC 166-31 'Rainha', IAC 21-14 'Madalena' and 'BRS Lorena' cultivars.

In Davis, USA few results differed between rootstocks $420 \mathrm{~A}$ (low vigor) and $110 \mathrm{R}$ (high vigor) in chemical characteristics from must of the 'Cabernet Sauvignon' grapevine. Grapes from rootstock 420A produced lower $\mathrm{pH}$ must than 110R, however other maturity indices like soluble solids content and titratable acidity were not different between the two rootstocks (LEE; STEENWERTH, 2013). Similarly, there was difference in soluble solids content and titratable acidity of the Bordô must on the ' $420 \mathrm{~A}$ ', 'IAC 766' and '106-8 Mgt' cultivated in Missal, PR (POZZAN et al., 2012).

In relation to the physicochemical characteristics of the wines (Table 2), there was no difference between the 'IAC 766' and '106-8 Mgt' rootstocks in the density of Bordô, Isabel and IAC 138-22 Máximo wines. The density is related to the alcohol content and reducing sugars of the wine (MANFROI et al., 2006).

All wines had alcohol content ranging from $11 \%$ to $12 \%(\mathrm{v} / \mathrm{v})$, thus all fit within the limits established by the Brazilian law for dry table wines, which is $8.6 \%$ to $14 \%(\mathrm{v} / \mathrm{v})$ (BRASIL, 2004). This occurred because there was no difference in soluble solids in the must and all samples had similar correction of alcohol by direct insertion of sucrose to wine. V. labrusca grapes generally do not accumulate enough sugar for the production of table wines with a suitable alcohol, requiring correction (RIZZON et al., 2000).

The limits recommended by the Brazilian legislation for the total wine acidity levels are 55 to $130 \mathrm{meq} \mathrm{L}^{-1}$ (BRASIL, 1988), therefore the Isabel and IAC 138-22 Máximo wines presented within the established limits. However, the Bordô wines had mean values of total acidity slightly below the minimum set, averaging between rootstocks of 52.2 meq $\mathrm{L}^{-1}$, differing from the results of Biasoto et al. (2014) in wines produced in the wineries of the State of São Paulo and Tecchio et al. (2007) in wines of Flores da Cunha, RS, who obtained values within the established limits.

There was no difference between the 'IAC 766' and '106-8 Mgt' rootstocks in the fixed acidity and total acidity of Bordô and Isabel wines, however in the IAC 138-22 Máximo wine obtained lower total acidity and fixed acidity in that elaborated from grapes grafted onto '106-8 Mgt' rootstock (Table 2), possibly because this rootstock promoted lowest total acidity in grape must (Table 1 ). The total acidity of IAC 138-22 Máximo wine on 'IAC 776' (98.33 meq $\mathrm{L}^{-1}$ ) was higher from those obtained by Biasoto et al. (2014) in the same wine (78.6 meq L $\left.\mathrm{L}^{-1}\right)$, however this value is similar to obtained when used the "106-8 Mgt' rootstock ( $\left.76.6 \mathrm{meq} \mathrm{L}^{-1}\right)$. There was a reduction in the total acidity of the wine in relation to must of Isabel and IAC 138-22 Máximo grapes.

There was a reduction in the total acidity of the wine in relation to must in the Isabel and IAC 138-22 Máximo vines, this may have occurred as a result of precipitation of potassium hydrogen tartrate and/or the reduction of malic acid during malolactic fermentation (MANFROI et al., 2006).

There was no difference in the volatile acidity among the 'IAC 766' and '106-8 Mgt' rootstocks in Bordô, Isabel and IAC 138-22 Máximo wines, with average values of $6.08,5.45$, and $5.45 \mathrm{meq} \mathrm{L}^{-1}$, 
respectively. These values are below the maximum allowed by the Brazilian law $\left(20\right.$ meq $\left.\mathrm{L}^{-1}\right)$ and are considered suitable for well-designed red wines, indicating proper conduct of alcoholic and malolactic fermentations (MANFROI et al., 2006).

There was no difference in $\mathrm{pH}$ among rootstocks in the IAC 138-22 Máximo and Bordô wine. The Bordô wine made from the grapes grafted on 'IAC 766' rootstock had an increase in $\mathrm{pH}$ in relation to must, while that in the Bordô wine made from grapes grafted on '106-8 Mgt' rootstock, there was a decrease in the values of $\mathrm{pH}$. The factors affecting the $\mathrm{pH}$ variation in winemaking are related to the release of organic acids and film minerals for the must, especially potassium (RIZZON; MIELE, $2002 b)$. The $\mathrm{pH}$ values obtained in Bordô wine by Biasoto et al. (2014), Castilhos et al. (2013) and Tecchio et al. (2007), 3.25, 3.3, and 3.21, respectively, are below those obtained in this study, however, closer to those seen with '106-8 Mgt' rootstock.

The Isabel wine made with grapes from 'IAC 766' rootstock had higher $\mathrm{pH}$ in relation to that elaborated with grapes from ' $106-8 \mathrm{Mgt}$ ' rootstock, with means values of 3.38 and 3.28 , respectively. These values are within the range observed by Rizzon et al. (2000) studying Isabel wine in vintages from 1988 to 1994 in Bento Gonçalves, RS, and obtained values ranging from 3.27 to 3.54 . The results of this study in Isabel wines in both rootstocks are also similar to those of Castilhos et al. (2013) and Rizzon and Miele (2006).

There was a reduction in $\mathrm{pH}$ in Isabel wine in relation to its must. The Isabel grapevine tends to lower the $\mathrm{pH}$ in different phases of winemaking, grape crushing, and bottling (RIZZON; MIELE, 2002b). In the IAC 138-22 Máximo wine, however, there was an increase in $\mathrm{pH}$ in the wine compared to must. The increase in the $\mathrm{pH}$ value in the transformation of the must into wine is assigned to the potassium extracted during maceration period and subsequent precipitation of the tartaric acid as bitartrate (RIZZON; MIELE, 2001).

There was no effect of the 'IAC 766' and '106-8 Mgt' rootstocks in the dry extract of the Isabel and IAC 138-22 Máximo wines, being the average values 24.43 and $24.44 \mathrm{~g} \mathrm{~L}^{-1}$, respectively. However, in the Bordô wine, there was higher dry matter values in elaborate wine with grapes grafted onto ' $106-8 \mathrm{Mgt}$ ' rootstock. The total dry extract has been regarded as one of the main elements that determine the structure and body of wines (RIZZON et al., 2000; CASTILHOS et al., 2013). The higher dry extract content positively affects the sensation of thickness of the wine in the mouth, which is an important characteristic, since that mouth feel is recognized as an important component of the wine quality (YANNIOTIS et al., 2007).

The reducing sugars concentration did not differ between the 'IAC 766' and '106-8 Mgt' rootstocks in the studied wines, certainly the fact that it was held equal chaptalization in all of them being obtained averages of 2.26; 1.41 and $2.18 \mathrm{~g}$ $\mathrm{L}^{-1}$, respectively, in Bordô, Isabel and IAC 138-22 Máximo wines. Low reducing sugar concentrations obtained indicate that fermentation occurred normally, turning the natural grape sugar and the one added in the chaptalization in alcohol in the alcoholic fermentation. According to the Brazilian legislation (BRASIL, 1988) the Bordô, Isabel and IAC 138-22 Máximo wines, in this study, are classified as "dry wines", and the maximum to fit in the classification of $4 \mathrm{~g} \mathrm{~L}^{-1}$ of glucose.

In the reduced dry extract, there were differences between the rootstocks only in Bordô wine, with concentrations of 24.88 and $25.81 \mathrm{mg}$ $\mathrm{L}^{-1}$, respectively in the 'IAC 766' and ' $106-8 \mathrm{Mgt}$ ' rootstocks. Thus, differences were also obtained in alcohol/reduced dry extract ratio of Bordô wine, with highest value obtained in 'IAC 766' rootstock. With concentration of dry extract lowered average of 24.04 and $23.25 \mathrm{mg} \mathrm{L}^{-1}$, and averages alcohol/ reduced dry extract ratio of 3.97 and 3.9, in the Isabel and IAC 138-22 Máximo wines, respectively, there were no differences among the rootstocks (Table 2). All values obtained from such analyzes are in agreement with the literature (RIZZON; MIELE, 2002b; TECCHIO et al., 2007; CASTILHOS et al., 2013). The Brazilian law (BRASIL, 1988) does not establish minimum value of reduced dry extract, but a maximum of alcohol/reduced dry extract ratio, set at 4.8 for ordinary red wines. No wine showed value of this ratio higher than the maximum established by that legislation.

The alcohol/reduced dry extract ratio provides an indication of the balance between fixed constituents of wine, represented by the reduced dry, and volatile extract, represented by alcohol. This relationship helps to indicate excess of chaptalization also being indicative to detect fraud (RIZZON et al. 2003; RIZZON, 2010).

In Bordô wines mean values of free sulfur dioxide and total sulfur dioxide were 25.33 and $54.13 \mathrm{mg} \mathrm{L}^{-1}$, respectively; in Isabel wines, 26.95 and $49.96 \mathrm{mg} \mathrm{L}^{-1}$; and in the IAC 138-22 Máximo wines the mean values were 28.44 and $50.85 \mathrm{mg} \mathrm{L}^{-1}$, respectively. The conservation of wine is favored by the concentration of $30 \mathrm{mg} \mathrm{L}^{-1}$ of free sulfur 
dioxide, and the values obtained in this study, near this concentration (ROSIER, 1995). The total sulfur dioxide concentrations in all the wines were below the maximum limit established by the legislation of $350 \mathrm{mg} \mathrm{L}^{-1}$.

There was no difference between the 'IAC 766' and '106-8 Mgt' rootstocks in total anthocyanins, polyphenols index (I 280), total polyphenols, total flavonoids and antioxidant activity in Bordô, Isabel and IAC 138-22 Máximo wines (Table 3).

The average total anthocyanins content in Bordô, Isabel and IAC 138-22 Máximo wines was $657.1 ; 38.64$ and $375.6 \mathrm{mg} \mathrm{L}^{-1}$, respectively. The anthocyanins content obtained in Bordô wine is within the range found by Tecchio et al. (2007) evaluating 13 samples of Bordô wines in Flores da Cunha wineries, RS, in which the authors obtained anthocyanin content ranging from 493.1 to $878.4 \mathrm{mg}$ $\mathrm{L}^{-1}$, with a mean of $778.8 \mathrm{mg} \mathrm{L}^{-1}$. Low anthocyanin content in Isabel wines were also obtained by Rizzon et al. (2000), and Rizzon and Miele (2006) in wines produced in the Serra Gaúcha, RS. Nixford and Hermosín-Gutierrez (2010) also found in lower levels of anthocyanins and Isabel wine mentioning that low levels of tannins can be expected.

It is not found in the literature studies indicating the anthocyanin content of IAC 138-22 Máximo wines, however the results obtained in this study, seems to have intermediate value between the Bordô and Isabel wines. The total anthocyanins content obtained in IAC 138-22 Máximo wine was similar to those found in wines from Vitis vinifera L., 'Cabernet Franc' (RIZZON; MIELE, 2001) and 'Cabernet Sauvignon' (RIZZON; MIELE, 2002a).

The average values among 'IAC 766' and '106-8 Mgt' rootstocks the polyphenol index (I 280 ) in Bordô, Isabel and IAC 138-22 Máximo wines was $94.5 ; 23.0$ and 60.5 , respectively. The red wines absorb substantial ultraviolet radiation with a minimum 280 to $282 \mathrm{~nm}$, mainly to absorption of the benzene nuclei characteristic of phenolic compounds principle used to determine the total polyphenol I 280 (RIZZON, 2010). The values obtained in Bordô and Isabel wines are in accordance with Tecchio et al. (2007) who obtained in Bordô wines levels of total polyphenols ranging from 48.5 to 104.1 and Rizzon et al. (2000), in which Isabel wines obtained average of 24.3. The Cabernet Franc and Cabernet Sauvignon wines were obtained total polyphenols index (I 280), respectively 25.3 and 31.8 (RIZZON; MIELE, 2001; RIZZON; MIELE, 2002a), values are lower than in the IAC 138-22 Máximo wine this study.

When determined by the Folin-Ciocalteu method, the wines total polyphenols did not differ among the 'IAC 766' and '106-8 Mgt' rootstocks, with averages values of $810.2 ; 221.8$ and $728.8 \mathrm{mg}$ AGE L $L^{-1}$ in Bordô, Isabel and IAC 138-22 Máximo wines, respectively. In Bordô wine, IAC 138-22 Máximo wine and in wine composed of Bordô and Isabel were obtained total polyphenol content superior to those of the present study (BIASOTO et al., 2014). Higher levels were also obtained by CASTILHOS et al. (2013) in Bordô (1232.7 $\mathrm{mg} \mathrm{L}^{-1}$ ) and Isabel wines (506.6 $\left.\mathrm{mg} \mathrm{L}^{-1}\right)$.

The phenolic composition of wine is conditioned by grape variety and other factors affecting the development of the berry, like the soil, geographic location and weather conditions. The occurrence of these substances in wine is not only a consequence of its extraction from grapes during the winemaking. Once the grapes are crushed, before the alcoholic fermentation, various condensation reactions involving some of these molecules (especially anthocyanins, catechins and procyanidins) occur, resulting in the formation of new polymeric pigments that are responsible for the wine color changes (PAIXÃO et al., 2007).

The mean total flavonoid contents of Bordô, Isabel and IAC 138-22 Máximo wines were 126.5; 28.2 and $115.2 \mathrm{mg} \mathrm{L}^{-1}$, respectively (Table 3 ). There are few data in the literature of total flavonoid content of wines evaluated in this study. Isabel wines obtained levels ranging from 61.8 to 150.6 mmol L ${ }^{-1}$ by chromatographic analysis (NIXFORD; HERMOSÍN-GUTIÉRREZ, 2010), higher than those obtained in this study in the same wine, which may be related to analysis method.

There was no difference between the 'IAC 766' and '106-8 Mgt' rootstocks in antioxidant activity of Bordô, Isabel and IAC 138-22 Máximo wines, being obtained averages $173.3 ; 38.9$ and 142.5 $\mu$ mol L $\mathrm{L}^{-1}$ of Trolox equivalent. Low antioxidant activity of Isabel wine corroborates with the Nixford and Hermosín-Gutiérrez (2010) study, who obtained values ranging from 2.55 to $6.25 \mathrm{mmol} \mathrm{L}^{-1}$ Trolox equivalent in Isabel wines made from grapes produced at different locations. 
TABLE 1 - Characteristics of the must of grapes for wine Bordô, Isabel and IAC 138-22 Máximo grafted on 'IAC 766' and '106-8 Mgt' rootstocks. Jundiaí-SP, 2013/2014.

\begin{tabular}{|c|c|c|c|c|c|c|c|c|c|}
\hline \multirow{2}{*}{ Variables $^{(1)}$} & \multicolumn{3}{|c|}{ Bordô } & \multicolumn{3}{|c|}{ Isabel } & \multicolumn{3}{|c|}{ IAC 138-22 Máximo } \\
\hline & IAC 766 & $106-8 \mathrm{Mgt}$ & $\mathrm{CV}(\%)$ & IAC 766 & $106-8 \mathrm{Mg}$ & $\mathrm{CV}(\%)$ & IAC 766 & $106-8 \mathrm{Mg}$ & CV $(\%)$ \\
\hline $\mathrm{pH}$ & $3.65 \mathrm{~b}$ & $3.69 \mathrm{a}$ & 0.42 & $3.54 \mathrm{a}$ & $3.46 \mathrm{a}$ & 1.20 & $3.50 \mathrm{a}$ & $3.51 \mathrm{a}$ & 1.81 \\
\hline $\mathrm{SS}\left({ }^{\circ} \mathrm{Brix}\right)^{(2)}$ & $17.27 \mathrm{a}$ & $17.53 \mathrm{a}$ & 1.76 & $18.23 \mathrm{a}$ & $18.03 \mathrm{a}$ & 4.01 & $15.23 \mathrm{a}$ & 15.77 & 3.28 \\
\hline $\mathrm{TA}\left(\text { meq } \mathrm{L}^{-1}\right)^{(3)}$ & $47.50 \mathrm{a}$ & $44.25 \mathrm{a}$ & 6.92 & $104.3 \mathrm{a}$ & $108.7 \mathrm{a}$ & 2.79 & $112.2 \mathrm{a}$ & $103.5 \mathrm{~b}$ & 5.33 \\
\hline $\mathrm{SS} / \mathrm{TA}$ ratio & $48.49 \mathrm{~b}$ & $52.86 \mathrm{a}$ & 2.48 & $23.33 \mathrm{a}$ & $22.13 \mathrm{a}$ & 5.46 & $18.19 \mathrm{a}$ & $20.31 \mathrm{a}$ & 6.36 \\
\hline
\end{tabular}

(1) The data followed the same letter on the line, within each grape must, are not statistically different by Tukey $(p<0.05)$.

${ }^{(2)}$ SS: soluble solids content. ${ }^{(3)} \mathrm{TA}$ : total acidity.

TABLE 2- Analytical profile of Bordô, Isabel and IAC 138-22 Máximo wines, from vines grafted on 'IAC 766' and '106-8 Mgt' rootstocks. Jundiaí-SP, 2013/2014.

\begin{tabular}{|c|c|c|c|c|c|c|c|c|c|}
\hline \multirow[b]{2}{*}{ ariables $^{(1)}$} & \multicolumn{3}{|c|}{ Bordô } & \multicolumn{3}{|c|}{ Isabel } & \multicolumn{3}{|c|}{ IAC 138-22 Máximo } \\
\hline & C 766 & $\begin{array}{c}106-8 \\
\mathrm{Mgt}\end{array}$ & $\begin{array}{l}\mathrm{CV} \\
(\%)\end{array}$ & IA & $\begin{array}{c}106-8 \\
\mathrm{Mgt}\end{array}$ & $\begin{array}{l}\mathrm{CV} \\
(\%)\end{array}$ & 66 & $\begin{array}{l}106-8 \\
\mathrm{Mgt}\end{array}$ & $\begin{array}{l}\mathrm{CV} \\
(\%)\end{array}$ \\
\hline Density ( & $8 \mathrm{a}$ & $0.997 \mathrm{a}$ & 0.04 & $\mathrm{a}$ & $0.995 \mathrm{a}$ & 0.09 & $6 \mathrm{a}$ & $0.997 \mathrm{a}$ & 0.10 \\
\hline Alcohol content $(\% \mathrm{v})$ & $11.33 \mathrm{a}$ & $11.24 \mathrm{a}$ & 2.20 & $11.94 \mathrm{a}$ & $11.77 \mathrm{a}$ & 4.81 & $11.44 \mathrm{a}$ & 11.12 & 4.70 \\
\hline Total acidity (meq L-1) & $52.42 \mathrm{a}$ & $52.00 \mathrm{a}$ & 2.47 & $88.06 \mathrm{a}$ & $96.83 \mathrm{a}$ & 6.60 & $98.33 \mathrm{a}$ & $76.00 \mathrm{~b}$ & 3.53 \\
\hline Volatile acidity $\left(\mathrm{meq} \mathrm{L} \mathrm{L}^{-1}\right)$ & $5.67 \mathrm{a}$ & $6.50 \mathrm{a}$ & 6.99 & $22 \mathrm{a}$ & $5.67 \mathrm{a}$ & 6.61 & $5.00 \mathrm{a}$ & $5.50 \mathrm{a}$ & 26.7 \\
\hline Fixed acidity $\left(\mathrm{meq} \mathrm{L}^{-1}\right)$ & $46.75 \mathrm{a}$ & $45.5 \mathrm{a}$ & 2.17 & $82.83 \mathrm{a}$ & $91.17 \mathrm{a}$ & 7.35 & $93.33 \mathrm{a}$ & $70.5 \mathrm{~b}$ & 3.26 \\
\hline $\mathrm{pH}$ & 34 a & $3.54 \mathrm{a}$ & 7.00 & & $3.28 \mathrm{~b}$ & 1.16 & $3.91 \mathrm{a}$ & $4.02 \mathrm{a}$ & 2.52 \\
\hline Dry extract $\left(\mathrm{g} \mathrm{L}^{-1}\right)$ & $0 \mathrm{~b}$ & 27. & 0 . & 6 a & $24.21 \mathrm{a}$ & 2 & $0 \mathrm{a}$ & $24.98 \mathrm{a}$ & 5.39 \\
\hline educing sugars $\left(\mathrm{g} \mathrm{L}^{-1}\right)$ & $1 \mathrm{a}$ & $2 \mathrm{a}$ & 10.4 & $5 \mathrm{a}$ & $1.47 \mathrm{a}$ & 21.6 & a & $2.12 \mathrm{a}$ & 12.3 \\
\hline Reduced dry extract $\left(\mathrm{g} \mathrm{L}^{-1}\right)$ & $24.88 \mathrm{~b}$ & $25.81 \mathrm{a}$ & 1.35 & $24.31 \mathrm{a}$ & $23.78 \mathrm{a}$ & 3.25 & $22.64 \mathrm{a}$ & $23.86 \mathrm{a}$ & 5.62 \\
\hline Alcohol/re & $3.65 \mathrm{a}$ & $3.48 \mathrm{~b}$ & 0.94 & $93 \mathrm{a}$ & $4.02 \mathrm{a}$ & 3.74 & $4.05 \mathrm{a}$ & $3.75 \mathrm{a}$ & 9.00 \\
\hline Free sulfur dioxide $\left(\mathrm{mg} \mathrm{L}^{-1}\right)$ & $25.07 \mathrm{a}$ & $25.60 \mathrm{a}$ & 12.0 & $28.09 \mathrm{a}$ & $25.81 \mathrm{a}$ & 13.8 & $27.38 \mathrm{a}$ & $29.51 \mathrm{a}$ & 6.85 \\
\hline Total sulfur dioxide $\left(\mathrm{mg} \mathrm{L}^{-1}\right)$ & $53.87 \mathrm{a}$ & $54.40 \mathrm{a}$ & 1.56 & $50.13 \mathrm{a}$ & $49.78 \mathrm{a}$ & 2.76 & $50.13 \mathrm{a}$ & $51.56 \mathrm{a}$ & 2.71 \\
\hline
\end{tabular}

${ }^{(1)}$ The data followed the same letter on the line, within each wine, are not statistically different by Tukey $(p<0.05)$.

TABLE 3- Polyphenol content of Bordô, Isabel and IAC 138-22 Máximo wines, from vines grafted on 'IAC 766' and '106-8 Mgt' rootstocks. Jundiaí-SP, 2013/2014.

\begin{tabular}{|c|c|c|c|c|c|c|c|c|}
\hline \multirow[b]{2}{*}{ Variables $^{(1)}$} & \multicolumn{3}{|c|}{ Bordô } & \multicolumn{2}{|c|}{ Isabel } & \multicolumn{3}{|c|}{ IAC 138-22 Máximo } \\
\hline & IAC 766 & $\begin{array}{l}106-8 \\
\mathrm{Mgt}\end{array}$ & $\begin{array}{l}\mathrm{CV} \\
(\%)\end{array}$ & IAC 766 & $\begin{array}{cc}106-8 & \mathrm{CV} \\
\mathrm{Mgt} & (\%)\end{array}$ & IAC 766 & $\begin{array}{c}106-8 \\
\mathrm{Mgt}\end{array}$ & $\begin{array}{l}\mathrm{CV} \\
(\%)\end{array}$ \\
\hline Anthocyanins (mg L-1) & $634.7 \mathrm{a}$ & $679.5 \mathrm{a}$ & 5.30 & $35.44 \mathrm{a}$ & 41.84 a 32.8 & $382.2 \mathrm{a}$ & 368.9 a & 11.9 \\
\hline Polyphenols index (I 280) & $92.87 \mathrm{a}$ & $96.20 \mathrm{a}$ & 4.53 & $22.82 \mathrm{a}$ & 23.23 a 6.59 & $59.62 \mathrm{a}$ & $61.42 \mathrm{a}$ & 7.11 \\
\hline Total polyphenols ${ }^{(2)}\left(\mathrm{mg} \mathrm{L}^{-1}\right)$ & $800.1 \mathrm{a}$ & $820.4 \mathrm{a}$ & 4.07 & $220.3 \mathrm{a}$ & 223.3 a 5.29 & $709.4 \mathrm{a}$ & $748.2 \mathrm{a}$ & 6.16 \\
\hline Total flavonoids ${ }^{(3)}\left(\mathrm{mg} \mathrm{L}^{-1}\right)$ & $126.4 \mathrm{a}$ & $126.7 \mathrm{a}$ & 6.94 & $27.71 \mathrm{a}$ & 28.68 a 11.2 & $122.5 \mathrm{a}$ & $107.8 \mathrm{a}$ & 12.9 \\
\hline Antioxidant activity ${ }^{(4)}\left(\mu \mathrm{g} \mathrm{L}^{-1}\right)$ & $170.9 \mathrm{a}$ & $175.6 \mathrm{a}$ & 2.15 & $39.31 \mathrm{a}$ & 38.66 a 3.97 & $142.0 \mathrm{a}$ & $143.0 \mathrm{a}$ & 2.34 \\
\hline
\end{tabular}




\section{CONCLUSIONS}

The '106-8 Mgt' rootstock promoted higher dry matter content and reduced dry extract in Bordô wine, and lower total and fixed acidity in IAC 13822 Máximo wine. In Isabel wine, higher $\mathrm{pH}$ was promoted by the 'IAC 766' rootstock.

There was no effect of rootstocks in the total phenolics content and antioxidant activity of wines.

The must of the Bordô, Isabel and IAC 13822 Máximo grapes had low soluble solids content for vinification. However, this characteristic occurs mainly because to the climatic characteristics of the region where these grapes were grown. Thus, due to the few differences obtained in musts and wines of these cultivars, both 'IAC 766' and '106-8 Mgt' rootstocks can be recommended for cultivation in the Jundiaí region.

\section{ACKNOWLEDGEMENTS}

To the Conselho Nacional de Desenvolvimento Científico e Tecnológico (CNPq) and to the Fundação de Amparo à Pesquisa do Estado de São Paulo (FAPESP) for granting master scholarship to the first author (Process n. 2013/25345-0) and for financial support (Process n. 2015/16440-5).

\section{REFERENCES}

BIASOTO, A. C. T.; NETTO, F. M.; MARQUES, E. J. N.; SILVA, M. A. A. P. Acceptability and preference drivers of red wines produced from Vitis labrusca and hybrid grapes. Food Research International, London, v.62, p.56-466, 2014.

BRAND-WILLIAMS, W.; CUVELIER, M. E.; BERSET, C. Use of a free radical method to evaluate antioxidant activity. Lebensmittel-Wissenschaft Und-Technologie, Wien, v.28, n.1, p.25-30, 1995.

BRASIL. Ministério da Agricultura. Portaria $n^{\circ}$ 229 , de 25 de outubro de 1988. Normas referentes à complementação dos padrões de identidade e qualidade do vinho e dos derivados da uva e do vinho. Diário Oficial da União, Brasília, DF, 31 out. 1988. Seção 1, 1988.
BRASIL. Ministério da Agricultura. Secretaria Nacional de Defesa Agropecuária. Complementação de padrões de identidade e qualidade do vinho e dos derivados da uva e do vinho. Brasília, DF, 2004. 21p.

BRASIL. Ministério da Saúde. Agência Nacional de Vigilância Sanitária. Métodos físico-químicos para análise de alimentos. Brasília, DF, 2005. 1018p.

BURIN, V.M.; COSTA, L.L.F.; ROSIER, J.P.; BORDIGNON-LUIZ, M.T. Cabernet Sauvignon wines from two different clones, characterization and evolution during bottle ageing. LWT - Food Science and Technology, Amsterdam, v.44, p.19311938,2011

CASTILHOS, M.B.M.; CATTELAN, M.G.; CONTI-SILVA, A.C.; BIACHI, V.L.D. Influence of two different vinification procedures on the physicochemical and sensory properties of Brazilian non-Vitis vinifera red wines. LWT - Food Science and Technology, Amsterdam, v.54, p.360-366, 2013.

HERNANDES, J.L.; PEDRO JÚNIOR, M.J.; SANTOS, A.O.; TECCHIO, M.A. Fenologia e produção de cultivares americanas e híbridas de uvas para vinho, em Jundiai-SP. Revista Brasileira Fruticultura, Jaboticabal, v.32, n.1, p.135-142, 2010.

LAGO-VANZELA, E.S.; DA-SILVA, R.; GOMES, E.; GARCÍA-ROMERO, E.; HERMANOSÍNGUTIÉRREZ, I. Phenolic composition of the edible parts (flesh and skin) of Bordô Grape (Vitis labrusca) Using HPLC-DAD-ESI-MS/MS. Journal of Agricultural and Food Chemistry, Washington, v.59, p.13136-13146, 2011

LEE, J.; STEENWERTH, K. L. 'Cabernet Sauvignon' grape anthocyanin increased by soil conservation practices. Scientia Horticulturae, New York, v.159, p.128-133, 2013.

MANFROI, L.; MIELE, A.; RIZZON, L.A.; BARRADAS, C.I.N. Composição físico-química do vinho Cabernet Franc proveniente de videiras conduzidas no sistema lira aberta. Ciência e Agrotecnologia, Lavras, v.30, n.4, p.787-792, 2006. 
MOTA, R.V.; SOUZA, C.R.; FEVERO, A.C.; SILVA, C.P.C.; CARMO, E.L.; FONSECA, A.R.; REGINA, M.A. Produtividade e composição físicoquímica de bagas de cultivares de uva em distintos porta-enxertos. Pesquisa Agropecuária Brasileira, Brasília, DF, v.44, n.6, p.576-582, 2009.

NELSON, N. A. A photometric adaptation of Somogyi method for the determination of glucose. Journal of Biological Chemistry, Baltimore. v.135, n.1, p.136-175, 1944.

NIXFORD, S.L.; HERMOSÍN-GUTIÉRREZ, I. Brazilian red wines made from the hybrid grape cultivar Isabel: Phenolic composition and antioxidant capacity. Analytica Chimica Acta, Amsterdam, v.659, p.208-215, 2010.

ORLANDO, T.G.S.; PEDRO JÚNIOR, M.J.; SANTOS A.O.; HERNANDES, J.L. Comportamento das cultivares Cabernet Sauvignon e Syrah em diferentes porta-enxertos. Ciência e Agrotecnologia, Lavras, v.32, n.3, p.749-755, 2008.

PAIXÃO, N.; PERESTRELO, R.; MARQUES, J.C.; CÂMARA, J.S. Relationship between antioxidant capacity and total phenolic content of red, rosé and white wines. Food Chemistry, London, v.105, p.204-214, 2007.

POPOVA, M.; BANKOVA, V.; BUTOYSKA, D.; PETKOV, V.; NIKOLOVA-DAMYANOVA, B.; SABATINI, A. G.; MARCAZZAN, G. L.; BOGDANOV, S. Validated methods for the quantification of biologically active constituents of poplar-type propolis. Phytochemical Analysis, New York, v.15, p.235-240, 2004.

POZZAN, M.S.V.; BRAGA, G.C.; SALIBE, A.B. Teores de antocianinas, fenóis totais, taninos e ácido ascórbico em uva 'bordô' sobre diferentes portaenxertos. Revista Ceres, Viçosa, MG, v.59, n.5, p.701-708, 2012.

RIZZON, L. A.; MENEGUZZO, J.; MANFROI, L. Planejamento e instalação de uma cantina para elaboração de vinho tinto. Bento Gonçalves: Embrapa Uva e Vinho, 2003. p.1-76. (Documentos, 37).

RIZZON, L. A.; MIELE, A. Acidez na vinificação em tinto das uvas Isabel, Cabernet Sauvignon e Cabernet Franc. Ciência Rural, Santa Maria, v.32, n.3, p.511-515, 2002b.
RIZZON, L. A.; MIELE, A. Avaliação da cv. Cabernet Franc para elaboração de vinho tinto. Ciência e Tecnologia de Alimentos, Campinas, v.21, n.2, p.249-255, 2001.

RIZZON, L. A.; MIELE, A. Avaliação da cv. Cabernet Sauvignon para elaboração de vinho tinto. Ciência e Tecnologia de Alimentos, Campinas, v.22, n.2, p.192-198, 2002a.

RIZZON, L. A.; MIELE, A. Efeito da safra vitícola na composição da uva, do mosto e do vinho Isabel da Serra Gaúcha, Brasil. Ciência Rural, Santa Maria, v.36, n.3, p.959-964, 2006.

RIZZON, L. A.; MIELE, A.; MENEGUZZO, J. Avaliação da uva cv. Isabel para a elaboração de vinho tinto. Ciência e Tecnologia de Alimentos, Campinas, v.20, n.1, p.115-121, 2000.

RIZZON, L. A.; ZANUZ, M. C.; MANFREDINI, S. Como elaborar vinho de qualidade na pequena propriedade. Bento Gonçalves: Embrapa Uva e Vinho, 1994. p.1-36. (Documentos, 12)

RIZZON, L.A. Metodologia para análise de vinho. Brasília, DF: Embrapa Informação Tecnológica, 2010. 120p.

ROSIER, J.P. Manual de elaboração de vinho para pequenas cantinas. 2.ed. Florianópolis: EPAGRI. 1995. 72p.

ROSSETTO, M.R.M.; VIANELLO, F.; ROCHA, S.A.; LIMA, G.P.P.Antioxidant substances and pesticide in parts of beet organic and conventional manure. African Journal of Plant Science, Lagos, v.3, p.245-253, 2009.

SATO, A.J.; SILVA, B.J.; BERTOLUCCI, R.; CARIELO, M.; GUIRAUD, M.C.; FONSECA, I.C.B.; ROBERTO, S.F. Evolução da maturação e características físico-químicas de uvas da cultivar Isabel sobre diferentes porta-enxertos na Região do Norte do Paraná. Semina: Ciências Agrárias, Londrina, v.30, n.1, p.11-20, 2009.

SILVA, M.J.R.; TECCHIO, M.A.; MOURA, M.F.; BRUNELLI, L.T.; IMAIZUMI, V.M.; VENTURINI FILHO, W.G. Composição físico-química do mosto e do vinho branco de cultivares de videiras em resposta a porta-enxertos. Pesquisa Agropecuária Brasileira, Brasília, DF, v.50, n.11, p.1105-1113, 2015. 
SINGLETON, V.L.; ROSSI Jr, J.A. Colorimetry of total phenolics with phosphomolybidicphosphotungstic acid reagents. American Journal of Enology and Viticulticulture, Davis, v.16, p.144$158,1965$.

TECCHIO, F.M.; MIELE, A.; RIZZON, L.A. Composição físico-química do vinho Bordô de Flores da Cunha, RS, elaborado com uvas maturadas em condições de baixa precipitação. Ciência Rural, Santa Maria, v.37, n. 5, p.1480-1483, 2007.
TECCHIO, M.A.; MOURA, M.F.; TEIXEIRA, L.A.J.; PAIOLI PIRES, E.J. Influence of rootstocks and pruning times on yield and on nutrient content and extraction in 'Niagara Rosada' grapevine. Pesquisa Agropecuária Brasileira, Brasília, DF, v.49, n.5, p.340-348, 2014.

YANNIOTIS, S.; KOTSERIDIS, G.; ORFANIDOU, A.; PETRAKI, A. Effect of ethanol, dry extract and glycerol on the viscosity of wine. Journal of Food Engineering, Amsterdam, v.81, n.2, p.399-403, 2007. 